Beyond Philology No. 17/1, 2020

ISSN 1732-1220, eISSN 2451-1498

https://doi.org/10.26881/bp.2020.1.04

\title{
Omani ESL learners perception of their pronunciation needs
}

\author{
ŁUKASZ ZARZYCKI
}

Received 12.03.2019,

received in revised form 13.07.2020,

accepted 14.07.2020

\begin{abstract}
The aim of this study is to analyze Omani ESL learners perception of their pronunciation needs, problems related to Omani students' pronunciation and strategies which students use to learn pronunciation. The paper also investigates if Omani students are conscious of their pronunciation obstacles. In this study, the observation and perception of Omani university students from Ad Dakhiliyah Region were examined in order to determine their pronunciation needs. As far as English as a Second Language (ESL) classes are concerned, language skills are frequently taught separately and teachers focus more on some skills i.e. grammar, reading, writing and vocabulary than on pronunciation. Seidlhofer (2000) states that some researchers have noted that teachers treat pronunciation skills as the "Cinderella" of ESL teaching and pronunciation is regarded as an extra add-on. It is essential to investigate for a teacher what aspects and strategies of teaching pronunciation are the best for ESL students. The method of data collection was a questionnaire using the sample questions presented by Derwing and Rossiter (2002). The questionnaire was distributed among Omani university learners in Ad Dakhiliyah Region. Students were asked to fill in the questionnaire and return it the next day. The major research problem is focused on the possibility of improvement of pronunciation teaching strategies. The research was
\end{abstract}


conducted by the author during his professional work as a university lecturer in the Ad Dakhiliyah region in the Sultanate of Oman.

\title{
Keywords
}

ESL, pronunciation needs, Omani ESL learners, strategies for pronunciation problems

\section{Postrzeganie wlasnych potrzeb w zakresie wymowy języka angielskiego przez studentów w Omanie}

\begin{abstract}
Abstrakt
Celem tego badania jest analiza percepcji omańskich uczniów uczących się języka angielskiego jako drugiego języka w zakresie ich potrzeb dotyczacych wymowy - problemów związanych $z$ wymowa języka angielskiego, strategii, których używają w nauce wymowy. Artykuł wykazuje także czy studenci omańscy są świadomi przeszkód jakie napotykaja w opanowywaniu wymowy angielskiej. W niniejszym badaniu wzięli udział studenci uniwersyteccy z regionu Ad Dakhiliyah. Podczas nauczania angielskiego jako drugiego języka nauczyciele często uczą umiejętności językowych osobno i koncentruja się bardziej na pozostałych umiejętnościach tj. gramatyce, czytaniu ze zrozumieniem, pisaniu i słownictwie. Seidlhofer (2000) stwierdza, że niektórzy badacze zauważyli, iż nauczyciele traktują umiejętności wymowy jako "Kopciuszka" w nauczaniu języka angielskiego jako drugiego a wymowa jest uważana za dodatkowe rozszerzenie. Dlatego niezbędne jest określenie przez nauczyciela jakie aspekty i strategie w nauczaniu wymowy sa najlepsze dla uczniów. Narzędziem w zbieraniu danych do przeprowadzenia tego badania był kwestionariusz wykorzystujacy przykładowe pytania przedstawione przez Derwing i Rossiter (2002). Kwestionariusz został rozdany studentom w regionie Ad Dakhiliyah i ucziowie zostali poproszeni o jego wypełnienie i zwrócenie go następnego dnia. Główny problem badawczy skupia się na możliwości poprawy strategii nauczania wymowy studentów arabskich. Badania zostały przeprowadzone przez autora podczas jego pobytu zawodowego jako wykładowcy uniwersyteckiego w regionie Ad Dakhiliyah w Sułtanacie Omanu.
\end{abstract}




\section{Słowa kluczowe}

nauczanie angielskiego jako drugiego języka, potrzeby związane $z$ wymowa, strategie dotyczace problemów $z$ wymowa języka angielskiego, studenci języka angielskiego w Omanie

\section{Introduction}

Researchers have not focused much on Omani ESL learners' strategies and their pronunciation needs. A significant number of educators teach pronunciation individually without paying much attention to some features of pronunciation (Yule 1989, Gilakjani 2011, Calvo Benzies 2013). Morley (1987) notices that for the last decades teachers who teach pronunciation have put emphasis on teaching suprasegmentals, i.e. intonation, rhythm and stress. On the other hand, teachers also stressed the importance of teaching segmental vowels and consonants. However, the significance of supersegmentals for communication in English is not clear (Levis 1999). Seidlhofer (2000) states that during ESL classes, educators teach language skills separately. Skills are concentrated on more than teaching pronunciation. Furthermore, pronunciation is ignored and some teachers believe that learning and teaching pronunciation skills ought to be postponed for the future when students achieve a higher level. It seems that pronunciation is regarded as an "add-on" which is frequently considered to be dull and not very beneficial by the teachers (Brown 2014). It is essential for pronunciation teachers to comprehend what aspects of pronunciation needs are significant for students. Then, it helps educators to focus on the pronunciation parts which learners regard as meaningful. Teachers ought to familiarize themselves with various techniques which ESL learners use to send their message when the pronunciation barrier is a problem in communication. 
This study is based on ideas implemented by Derwing and Rossiter (2002). Fourteen years ago, Breitkreutz, Derwing and Rossiter (2001) conducted a survey to determine the nature and extent of pronunciation instruction in English-as-asecond-language (ESL) classrooms in Canada. The "era" of communicative language teaching (CLT) had marked a "fall from grace" for pronunciation instruction (Isaacs 2009: 2).

\section{The history and scope of pronunciation teaching}

Kelly (1969) calls pronunciation the "Cinderella" of foreign language teaching. Two general approaches to the teaching of pronunciation have been presented within the field of modern language teaching: (1) an intuitive-imitative approach and (2) an analytic-linguistic approach. An intuitive-imitative approach is defined as follows:

It depends on the learner's ability to listen to and imitate the rhythms and sounds of the target language without the intervention of any explicit information; it also presupposes the availability of good models to listen to, a possibility that has been enhanced by the availability first of phonograph records, then of tape recorders and language labs in the mid-twentieth century, and more recently of audio- and videocassettes and compact discs. (Celce-Murcia, Briton and Goodwin 1996: 2)

On the other hand, an analytic-linguistic approach is explained by Celce-Murcia et al. (1996: 2) as follows:

It utilizes information and tools such as a phonetic alphabet, articulatory descriptions, charts of vocal apparatus, contrastive information, and other aids to supplement listening, imitation, and production. It explicitly informs the learner of and focuses attention on the sounds and rhythms of the target language. This approach was developed to complement rather than to replace the intuitive-imitative approach, which was typically retained as the practice phase used in tandem with phonetic information. 
In the late 1800 s and early 1900s, pronunciation is lectured with the help of intuition and imitation. This approach is defined as Direct Method. Students are to imitate a certain model. This could be a teacher or a audio recording (Celce-Murcia, Brinton, Goodwin, Grinder 2010). Asher's (1977) Total Physical Response (TPR) is another language teaching methodology. Its characteristic feature is the combination of language studying with physical movement. TPR is similar to models of first language acquisition where understanding comes before output. Asher's attention to developing comprehension skills before the student is taught how to speak brings him to socalled Comprehension Approach (Winitz 1981) which claims that

1. Comprehension abilities precede productive skills in learning a language;

2. The teaching of speaking should be delayed until comprehension skills are established;

3. Skills acquired through listening transfer to other skills;

4. Teaching should emphasize meaning rather than form

5. Teaching should minimize learner stress.

(Richard and Rodgers 2014: 278)

By implementing Comprehension Approach in the classroom students spend a certain amount of time only on listening before they are allowed to talk. They can repeat the words which seem to be difficult to pronounce for them.

The first linguistic approach to the teaching of pronunciation was formed in the 1890s as the Reform Movement. Phoneticians such as Henry Sweet, Wilhelm Viëtor, and Paul Passy formed the International Phonetic Association in 1886 and developed the International Phonetic Alphabet (IPA). The phoneticians advocated the following ideas and notions:

1. The spoken form of a language is primary and should be taught first. 
2. The findings of phonetics should be applied to language teaching.

3. Teachers must have solid training in phonetics.

4. Learners should be given phonetic training to establish good speech habits.

(Celce-Murcia, Briton and Goodwin 1996: 3)

Howatt (1984) believes that the Reform Movement played a significant role in the development of Audiolingualism in the United States and Oral Approach in Britain during the 1940s and 1950s. In both methods, pronunciation is very important and is taught explicitly from the beginning. The educator (or an audio recording) models a sound and learners repeat or imitate it. The teacher can also implement a technique which is called the minimal pair drill. This technique uses the contrast - words which are different by a single sound in the same position.

The introduction of the Cognitive Approach in the 1960s resulted in the downfall of Audiolingualism. This approach based on Chomsky's theory of transformational grammar which treated language as a rule-governed system paid attention to grammar and vocabulary. Thus, pronunciation teaching was discarded and learners had to rely on their intuition.

Caleb Gattengo introduced the Silent Way method in the 1970s. The goal of this method is to self-express in the target language. A learner should be independent and should develop his or her own ability to evaluate correctness. Teachers, on the other hand, should be silent most of the time and monitor students' errors. Peer correction is allowed so that students are believed to be comfortable with each other. It is also claimed that students can learn during sleeping. Teacher should be silent whenever possible. Therefore, educators use colored wooden rods, color-coded pronunciation charts and vocabulary charts (see Candlin and Mercer 2001: 153). Little emphasis was put on in the late 1970s when the Communicative Language Teaching method was introduced. CLT discard- 
ed pronunciation treating it as a challenging characteristic due to the premise that teaching pronunciation would hamper communicative process and could be adverse to the learners' self-confidence (Binte Habib 2013). CLT was described by Richards and Rogers (1986: 66) as: an approach that aims to (a) make communicative competence the goal of language teaching and (b) develop procedures for the teaching of the four language skills that acknowledge the interdependence of language and communication. Furthermore, Richards and Rogers (1986: 72) distinguished three aspects which represent CLT classroom practice:

One such element might be described as the communication principle: Activities that promote real communication promote learning. A second element is the task principle: Activities in which language is used for carrying out meaningful tasks promote learning. A third element is the meaningfulness principle: Language that is meaningful to the learner supports the learning process.

Another approach - Suggestopedia - is known for its usage of music to form a non-threatening atmosphere conducive to learning. Lozanov, who introduced this method, stated that language learning based on his method could be 25 times more effective than other methods (Lozanov 1978). Lozanov claims that Suggestopedia directs learners to "acts of communication" (Lozanov 1978: 109). The formation of the proper environment and the faith of students in the system is what characterizes Suggestopedia (Lozanov 1978: 154). The three methods that were introduced during the 1970s demonstrated interesting contrasts in the way they cope with pronunciation. In 1983 Krashen and Terrell published The Natural Approach which was composed of Krashen's theoretical viewpoints and Terrell's instructions how to implement the theoretical viewpoints in the classroom environment (Krashen and Terrell 1983). Krashen distinguished between conscious learning and 
"acquisition". Candlin and Mercer (2001: 159) clarify this distinction as follows:

Only language which is 'acquired' is seen as being available for natural language use. Language which has been 'learnt' can be used to monitor and correct output based on 'acquired' learning [...] Learners 'acquire' new language by being exposed to 'comprehensible input'. Such input is defined by Krashen as being comprehensible to the learner but containing language just above the learner's current level. According to Krashen it is only comprehensible input which facilitates acquisition, learner output is essentially irrelevant. Also according to Krashen learners are only able to acquire new grammatical structures in a certain order. This is called the "Natural Order Hypothesis".

Moreover, Krashen believed that learning was determined by student's emotions and feelings and that students who are not motivated and self-confident enough or are distressed, do not do as well as learners who are self-confident and are willing to study. During the 1990s and 2000s two opposing approaches were sustained: the nativeness principle and the intelligibility principle. The first principle states that "it is both possible and desirable to achieve native-like pronunciation in a foreign language" (Levis 2005: 370); however, Flege (1999) and Scovel (2000) claim that it is impossible to achieve for average learners with the exception of some clever ones. On the other hand, Munro and Derwing (1995: 75) characterize intelligibility as "the extent to which a speaker's message is actually understood by a listener" or in other words: "learners simply need to be understood" (Levis 2005: 370). Researchers have long been paying attention to segmental and suprasegmental features of speech. Educators have begun to focus on teaching suprasegmental features of language (i.e. rhythm, stress, and intonation) (Celce-Murcia et al. 2010: 11). McNerney and Mendelsohn (1992: 186) describe how a course of pronunciation should be organized: 
A short term pronunciation course should focus first and foremost on suprasegmentals as they have the greatest impact on the comprehensibility of the learner's English. We have found that giving priority to the suprasegmental aspects of English not only improves learners' comprehensibility but is also less frustrating for students because greater change can be effected in a short time.

Nowadays pronunciation courses of instruction try to implement both segmental and suprasegmental features of pronunciation. The following chart illustrates the development of pronunciation teaching.

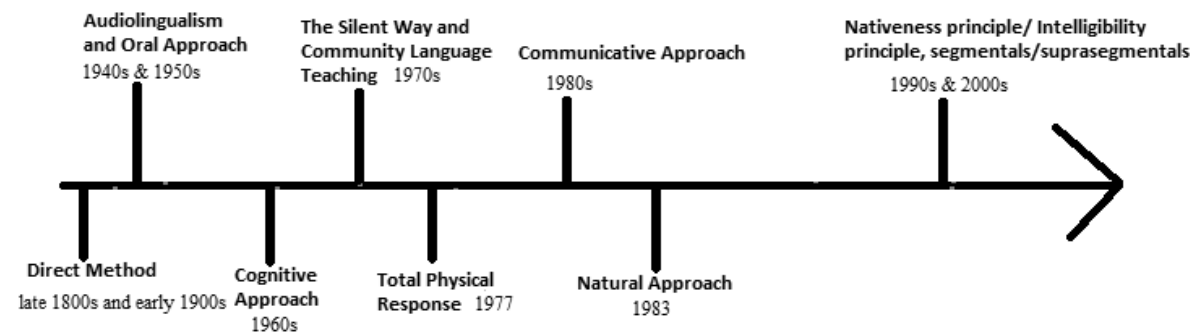

Figure 1

The history of pronunciation teaching

\section{ESL Students' attitudes towards English varieties}

In this section, students' attitudes towards English varieties will be explored. There are a few studies which reveal students' perception towards their accent preference. Flowerdew (1994) stated that students understand the speaker when he or she speaks with the same variety of English as students. Furthermore, Wilcox (1978) examined students of English from Singapore and noticed that it is easier for them to understand when they listen to a speaker who comes from the same country. However, another study conducted by Smith and Bisazza (1982) showed that Indians understood US speaker easier than their own variety. 
Another aspect that affects students' attitude towards accent preference is the negative perception of second language speakers which frequently relates to stereotypes. Such stereotypes are based on the observation that speakers whose English is not a mother tongue are believed to come from a lower class (Brennan and Brennan 1981). Australian children qualified Italian and Vietnamese speakers of English as those coming from a lower economic class (Nesdale and Rooney 1996). Rubin and Smith (1990) found that native English speakers judged instructors as having poor teaching skills. All the above studies show that students base on their personal attitudes, perceptions and experiences they had within the classroom environment.

Ethnicity is another important factor that has a significant impact on students' attitude towards accent preference. Bresnahan et al. (2002) investigated learners in an American university and showed that clear accents were thought to be more positive when comparing them to less intelligible ones.

Lindemann's study (2002) showed that American English speakers had a negative attitude towards Korean speakers of English because of its non-nativeness. Moreover Lindermann (2003) investigated that if foreign English is observed as faulty English, it is associated with a lack of intelligence or education (see Kawanami and Kawanami 2009: 7-10).

\section{Factors affecting Omani ESL learners pronunciation problems}

Omani ESL learners experience certain pronunciation obstacles which are related to recognition and production of different English speech sounds (both vowels and consonants). Many of these issues concern the fairly complex orthographic system of the English language and the incoherent relationship between English and Arabic (here Omani Arabic). Omani Arabic often causes a significant difficulty in pronunciation of English due to the Arabic interference in the English language. 
The English language consists of twenty-four consonants whilst Arabic consists of twenty-eight (see Table 1).

Table 1

English and Arabic consonant sounds

(Al Yaqoobi, Ali and Sulan 2016: 61)

\begin{tabular}{|c|c|c|}
\hline \multirow{2}{*}{$\begin{array}{l}\text { Same consonant } \\
\text { sounds in both } \\
\text { languages }\end{array}$} & \multicolumn{2}{|c|}{$\begin{array}{l}\text { Different consonant sounds } \\
\text { between languages }\end{array}$} \\
\hline & English & Arabic \\
\hline $\begin{array}{c}/ \mathrm{b} /, / \mathrm{d} / \\
/ \mathrm{d} /, / \mathrm{f} / \\
/ \mathrm{h} /, / \mathrm{j} / \\
/ \mathrm{k} /, / \mathrm{l} / \\
/ \mathrm{m} /, / \mathrm{n} / \\
/ \mathrm{r} /, / \mathrm{s} / \\
/ \mathrm{J} /, / \mathrm{t} / \\
/ \mathrm{e} /, / \mathrm{w} / \\
/ \mathrm{z} /, / \mathrm{z} /\end{array}$ & $\begin{array}{l}/ \mathrm{d} / \\
/ \mathrm{g} / \\
/ \mathrm{g} / \\
/ \mathrm{y} / \\
/ \mathrm{v} / \\
/ \mathrm{p} /\end{array}$ & 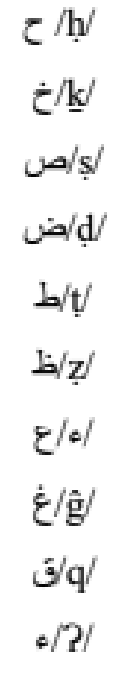 \\
\hline
\end{tabular}

Omani ESL learners face difficulties in producing particular English sounds which are missing in Arabic. Certain consonant sounds are present in both English and Arabic but others are used only in one language. Thakur (2020: 29) found the following pronunciation problems in her study:

The recurrent problems which surfaced in the spoken English of Omani learners involved in this study were pure vowel substitution for diphthongs / $/$ / and /eI/, replacement of /p/ by /b/ sound, insertion of the vowel sound /I/ while pluralizing the words, syllabification of initial and final consonant clusters, de- 
letion of /s/ sound occuring as the final element from consonant clusters, the alternation between $/ \mathrm{d} /$ and $/ \mathrm{g} /, / 3 /$ and $/ \mathrm{d} /, / \mathrm{g} /$ and $/ \mathrm{S} /$ sounds, replacement of $/ \mathrm{t} / \mathrm{vt} / \mathrm{t} / \mathrm{s}$ sound, lengthening of certain vowel sounds, pronouncing ' $r$ ' in all phonetic environments, irregularities in the use of weak forms, and not following the rules of aspiration.

Omani learners encounter numerous significant difficulties in producing some English sounds. The major factors which cause these problems arise from the mother tongue interference (here Omani Arabic variety): confusing certain sounds which exist in the English language or due to the inexistence of some English sounds in Arabic. Finally, other difficulties concerning correct pronunciation are caused by the lack of learner's knowledge of the English pronunciation rules.

\section{Students' strategies for dealing with pronunciation problems}

According to Nunan (1993), teachers should know what their students want to learn and they should figure out how their students want to learn. Researchers have concentrated on the strategies learners use to cope with pronunciation problems. It is essential for teachers to know the strategies which ESL learners prefer to implement in their language studying. Peterson's study (2000) investigated twelve pronunciation learning strategies adult students of Spanish as a foreign language use to improve their pronunciation skills in Spanish. There were found 43 specific tactics. The results showed that students used the cognitive strategies, for example, practicing naturalistically and practicing with sounds. In contrast, students did not prefer strategies that were based on memory or compensation.

Derwing and Rossiter (2002) demonstrate that students use different strategies, such as paraphrase, self-repetition, writing or spelling, volume adjustment, speaking clearly and 
slowing the speech rate when they encounter communication problems. Osburne (2003) examined fifty adult ESL students at colleges, universities and language institutes. The research was based on oral protocols to study L2 pronunciation. The research showed that the respondents used different techniques such as voice quality, individual sounds or clusters, individual syllables or words, prosodic structure, memory and imitation.

Savignon and Wang (2003) conducted a study in order to investigate students' attitudes concerning classroom practices. A questionnaire was the data collection method which was for their study. The findings showed that those students who had started studying English before entering high school had more negative attitude towards form-focused instruction than those who started learning English at high school (Kolokdaragh 2009). Fang and Lin's (2012) study investigated the nature of two learning contexts, computer-assisted pronunciation training (CAPT) and classroom-based pronunciation training (CBPT). One hundred twenty valid questionnaires were collected from college students who learned in CAPT and CBPT at one university in Taiwan. The study showed that in both learning contexts, the learners relied on memory and imitation.

Providing the research findings over two decades, the questions arise:

1. Are Omani ESL students conscious of their pronunciation obstacles?

2. What kind of techniques do they implement in order to study pronunciation?

3. What strategies do Omani students need to employ to improve their pronunciation?

\section{The questionnaire and participants}

A descriptive research design was used for this study. The questionnaire was based on Breitkreutz et al.'s (2001) study 
and mostly on Kologdaragh's (2009) questionnaire which was modified by the author. The author decided to use this specific questionnaire because the questions presented in the above study help to show weaknesses of Omani students. Respondents in the study were 50 Omani ESL learners (20 females and 30 males) who attend English classes at universities and colleges in Ad Dakhiliyah Region in Oman. The age of students was from 18 to 27 and they all were the nationals of Oman. According to their education level, 22 students were at the intermediate level and upper-intermediate level of English. The questionnaire was based on Breitkreutz, Derwing and Rossiter's (2001) questions and the scale used in this study was yes/no. The questionnaire consists of 29 questions concerning information on several topics such as some background information, pronunciation problems, pronunciation learning strategies or techniques, student's learning needs, and open questions.

\section{Results}

The respondents were requested to respond to the questions concerning their pronunciation problems. $72 \%$ of respondents answered that they are conscious of their pronunciation problems and only $25 \%$ claimed that their problems with communication result from their pronunciation problems. Moreover, $9 \%$ of learners answered that it is difficult for other people to understand their pronunciation.

The study showed that the most favored pronunciation strategy or technique was paraphrasing (85\%), asking a teacher $(74 \%)$ and listening to music $(65 \%)$, noticing contrast between native language and target language (54\%), writing pronunciation of words in their native language (45\%), paying attention to their own pronunciation and correcting it while speaking (38\%), speaking slowly to have correct pronunciation $(32 \%)$, trying to understand pronunciation rules $(27 \%)$, pronouncing difficult words loudly (22\%), paying attention to peo- 
ple's mouth movement when they are speaking (18\%), writing pronunciation rules in English (3\%). 82\% of respondents stated that they are not good at intonation and stress and $71 \%$ stated that they are not good at producing sounds that are absent in their native language. $86 \%$ of the learners answered that they did not take any pronunciation classes and $74 \%$ wanted to participate in pronunciation classes if they were offered.

As far as the open questions are concerned, the Omani ESL students were asked which aspect of pronunciation is more important: segmental or suprasegmental. Before the distribution of the questionnaire, both terms had been explained to the students. The learners could choose only one option when answering this question. 59\% reported that both aspects are important, $21 \%$ - suprasegmental, 16\% - segmental, and $4 \%$ of the respondents had no idea.

Moreover, the respondents were asked to enumerate other pronunciation problems they may have. Almost $55 \%$ of the learners did not know what other problems with pronunciation they have, $35 \%$ - the pronunciation of $/ \mathrm{b} /$ in place of $/ \mathrm{p} /$, $10 \%$ - the variety of English accents among native speakers.

The students were also asked to list other strategies or techniques to learn pronunciation. More than half of the respondents did not know what strategies they use, 35\% mentioned watching films, $10 \%$ - listening to music and $5 \%-$ memorizing. It is interesting that the respondents did not mention any dictionary in learning pronunciation.

Finally, the Omani ESL learners were asked to suggest some techniques or strategies for teaching pronunciation so that the teacher would implement them. 64\% of the respondents suggested watching films in English or playing music in class, $18 \%$ - teaching pronunciation rules, $10 \%$ - speaking slowly and repeating, and $8 \%$ - studying pronunciation from the very beginning. 


\section{Discussion and conclusions}

In this research, I examined Omani ESL learners' perception of their pronunciation. The results of this study show that ESL learners do not focus much on learning pronunciation. Although students would like to participate in extra pronunciation classes, they have no opportunity or enough instruction. Furthermore, the results reveal that ESL Omani students are conscious of their pronunciation obstacles; however, ESL teachers might not be acquainted with the way how pronunciation strategies should be taught so that students can implement them and, as a result, cope with communication obstacles. When students face pronunciation difficulties, they tend to use paraphrasing and asking the teacher as the preferred techniques.

Numerous respondents mentioned that they face problems related to intonation and stress. None of the students who participated in this study mentioned the use of dictionary for learning pronunciation. Perhaps students are not familiar with phonetic transcription and as a result they are not able to study pronunciation using a dictionary. More than half of Omani students reported that both segmental and suprasegmental aspects of teaching pronunciation are equally important. Students do know what other aspects of pronunciation are difficult for them; however, some students enumerate the fact that they reverse the pronunciation of $/ \mathrm{b} /$ and $/ \mathrm{p} /$. Odisho (2005: 61) states that "this sound happens to be a source of a major problem for Arab learners of English". Odisho (2005: 61) provides two reasons: "First, Arabic does not have this sound as part of its phonology, in other words, it is phonologically irrelevant though phonetically the sound may occur in certain contexts. Second, English has hundreds, perhaps even thousands, of words whose meaning is distinguished or triggered by contrasts of /b/ and /p/. Teachers also expose Omani ESL learners to English varieties what students enumerate as another difficulty. 
Watching films and listening to music are both very common techniques of improving students' pronunciation. Thus, most students suggested implementing both techniques in the classroom practice. Moreover, students prefer to write pronunciation of words in Arabic than in English. When teaching pronunciation, teachers should take into account the two aspects mentioned above because almost $50 \%$ of students who participated in the study prefer watching films and listening to music to improve their pronunciation.

In conclusion, I suggest the following recommendations for ESL programs and teachers in Oman. The first recommendation is that the implementation of phonetic transcription at the beginning level should be the primary goal of pronunciation instruction since the Omani students cannot read and write phonetic transcription of English (3\% of students can write pronunciation rules in English).

Another recommendation is to let the students work with dictionaries during their classes since respondents of this study did not use dictionary to study pronunciation. If students are familiar with phonetic alphabet, they are able to learn how to pronounce words with the help of a dictionary.

\section{References}

Al Yaqoobi, Zainab Mohammed, Fatimah Ali, Norrihan Sulan (2016). "An analysis of errors caused by Omani EFL learners in pronouncing certain consonant sounds". International Journal of Language Education and Applied Linguistics (IJLEAL) 5: 59-71.

Breitkreutz, Judy, Derwing, Tracey, Rossiter, Marian (2001). "Pronunciation teaching practices in Canada". TESL Canada Journal 19: 51-6.

Brennan, Eileen, John Stephen Brennan (1981). "Measurements of accent and attitude toward Mexican-American speech". Journal of Psycholinguistic Research 10: 487-501.

Bresnahan, Mary Jiang, Rie Ohashi, Reiko Nebashi, Wen Ying Liu, Sachiyo Morinaga Shearman (2002). "Attitudinal and affective 
response toward accented English". Language and Communication 22: 171-185.

Brown, Adam (2014). Pronunciation and Phonetics: A Practical Guide for English Language Teachers. Routledge.

Calvo Benzies, Yolanda Joy (2013). "Spanish EFL university students' views on teaching of pronunciation: A survey-based study". Language Studies Working Papers 5: 41-49.

Candlin, Christopher, Neil Mercer (eds.) (2001). English Language Teaching in Its Social Context. London: Routledge.

Celce-Murcia, Marianne, Donna Brinton, Janet Goodwin (1996). Teaching Pronunciation: A Reference for Teachers of English to Speakers of Other Languages. Cambridge: Cambridge University Press.

Celce-Murcia, Marianne, Donna Brinton, Janet Goodwin (2010). Teaching Pronunciation Hardback with Audio CDs (2): A Course Book and Reference Guide. Cambridge: Cambridge University Press.

Derwing, Tracey, Marian Rossiter (2002). "ESL learner's perception of their pronunciation needs and strategies". System 30: 155-166.

Fang, Ting, Chih-Cheng Lin (2012). "Taiwan EFL learners' pronunciation strategies in two learning contexts". Journal of Language Teaching and Research 3/5: 887-897.

Flege, James (1999). "Age of learning and second-language speech". In: D. P. Birdsong (ed.). Second Language Acquisition and the Critical Period Hypothesis. Hillsdale, NJ: Lawrence Erlbaum Associates, 101-132.

Flowerdew, John (1994). "Research of relevance to second language lecture comprehension - an overview". In: John Flowerdew (ed.). Academic Listening. New York: Cambridge University Press, 7-29.

Gattengo, Caleb (1972). Teaching Foreign Languages in Schools: The Silent Way. 2nd edition. New York: Educational Solutions.

Gilakjani, Abbas Pourhosein (2011). "A study on the situation of pronunciation instruction in ESL/EFL classrooms". Journal of Studies in Education 1/1: Paper 4.

Howatt, Anthony (1984). "Language teaching traditions: 1884 revisited". ELT Journal Volume 38/4: 279-282.

Isaacs, Talia (2009). "Integrating form and meaning in L2 pronunciation instruction". TESL Canada Journal 27: 1-12. 
Kawanami, Sachiyo, Kazuya Kawanami (2009). "Evaluation of Word Englishes among Japanese Junior and Senior High School Students". Second Language Studies, 27/2: 1-69.

Kelly, Louis (1969). 25 Centuries of Language Teaching: An Inquiry into the Science, Art, and Development of Language Teaching Methodology, 500B.C.-1969. Rowley, Mass: Newbury House Publishers.

Kolokdaragh, Vahideh Rasekhi (2009). ESL/EFL Perception of Their Pronunciation Needs and Strategies. Available at <http://64.8. 104.26/11kolokdaragh.pdf>.

Krashen, Stephen, Tracy Terrell (1983). The Natural Approach: Language Acquisition in the Classroom. Oxford: Pergamon.

Levis, John (1999). "Intonation in theory and in practice, revisited". TESOL Quarterly 33: 37-54.

Levis, John (2005). "Changing contexts and shifting paradigms in pronunciation teaching”. TESOL Quarterly 39/3: 369-377.

Lindemann, Stephanie (2002). "Listening with an attitude: A model of native speaker comprehension of non-native speakers in the United States". Language in Society 31: 419-441.

Lindemann, Stephanie (2003). "Koreans, Chinese or Indians? Attitudes and ideologies about non-native English speakers in the United States". Journal of Sociolinguistics 7: 348-364.

Nesdale, Drew, Rosanna Rooney (1996). "Evaluations and stereotyping of accent speakers by pre-adolescent children". Journal of Language and Social Psychology 15: 133-155.

McNerney, Maureen, Meldelsohn, David (1992). "Suprasegmentals in the pronunciation class: Setting priorities". In Peter Avery, Susan Ehrlich (eds.). Teaching American English pronunciation. Oxford: Oxford University Press, 185-196.

Morley, Joan (1987). Current Perspectives on Pronunciation. Alexandria, VA: TESOL.

Munro, Murray, Tracey Derwing (1995). "Processing time, accent, and comprehensibility in the perception of native and foreignaccent speech". Language and Speech 38/3: 289-306.

Nunan, David (1993). "From learning-centeredness to learnercenteredness". Applied Language Learning 4: 1-18.

Odisho, Edward (2005). Techniques of Teaching Comparative Pronunciation in Arabic and English. Gorgias Press LLC. 
Osburne, Andrea (2003). "Pronunciation strategies of advanced ESOL learners". International Review of Applied Linguistics in Language Teaching 41/2: 131-143.

Peterson, Susan (2000). Pronunciation Learning Strategies: A First Look. Available at <http://www.eric.ed.gov:80/ERICDocs/data/ ericdocs2sq1/content_storage_01/0000019b/80/16/de/8a.pdf>. Accessed 12.03.2009.

Richards, Jack, Theodore Rodgers (2014). Approaches and Methods in Language Teaching. Cambridge: Cambridge University Press.

Rubin, Donald, Kim Smith (1990). "Effects of accent, ethnicity, and lecture topic on undergraduates' perceptions of nonnative English-speaking teaching assistants". International Journal of Intercultural Relations 14: 337-353.

Savignon, Sandra, Wang Chaochang (2003). "Communicative language teaching in EFL contexts: Learners attitude and perception". International Review of Applied Linguistics in Language Teaching 41/3: 223-249. Available at <http://www.referenceglobal.com/doi/abs/10.1515/iral.2003.010>.

Seidlhofer, Barbara (2000). "Mind the gap: English as a mother tongue versus English as a lingua franca". University of Vienna Department of English Views 9/1: 51-68.

Scovel, Thomas (2000). "A critical review of the critical period research". Annual Review of Applied Linguistics 20: 213-223.

Smith, Larry, John Bisazza (1982). "The comprehensibility of three varieties of English for college students in seven countries". Language Learning 32: 129-269.

Thakur, Vijay Singh (2020). "Phonological problems of Omani EFL learners: Pedagogical perspectives and implications". Arab World English Journal (AWEJ) 11/1: 29-43.

Wilcox, George (1978). "The effect of accent on listening comprehension: A Singapore study". English Language Teaching Journal 32: 118-127.

Winitz, Harris (1981). The Comprehension Approach to Foreign Language Instruction. Rowley, MA: Newbury House.

Yule, George (1990). Review of Teaching English Pronunciation; Current Perspectives on Pronunciation: Practices Anchored in Theory; and Teaching Pronunciation: English Rhythm and Stress. System 18: $107-111$. 


\section{Appendix}

Please answer the following questions:
1. Gender:
a. Male
b. Female

2. Your English level:

a. Intermediate

b. Upper-intermediate

3. What is your first language?

4. At what age did you start learning English?

5. How long have you been learning English?

6. Do you speak any other languages?

7. When I have problems communicating, it is more likely because of pronunciation problems.

8. I know my main pronunciation problem areas.

9. It is difficult for people to understand my pronunciation.

10. I have not taken any pronunciation courses.

11. I would take a pronunciation course if it were offered.

12. I listen to music/TV/films as much as possible.

13. I usually pronounce loudly words that are difficult.

14. I try to understand pronunciation rules.

15. I pay attention to my pronunciation when I am talking.

16. I speak slowly in order to have correct pronunciation.

17. I notice people's mouth movement when they are speaking in English.

18. I notice contrasts between my native language pronunciations and English language pronunciations.

19. I paraphrase what I want to say if the listener cannot understand me.

20. I write down the pronunciation of words in English.

21. I write down the pronunciation of words in my native language.

22. I can correct my pronunciation when I am speaking.

23. If I do not know how to pronounce a word, I ask a native speaker.

24. I am not good at pronouncing just the sounds that are absent in my native language.

25. I am not good at having correct intonation and stress.

26. Which one do you think is more important? Suprasegmental (stress, intonation, and accent), segmental (vowels, consonants), both or you have no idea?

27. What are other problems you have in pronunciation?

28. What are other strategies you use in your pronunciation? 
29. What suggestions do you have for teachers? How should they teach pronunciation?

Łukasz Zarzycki

ORCID ID: 0000-0003-1433-0302

Pedagogical University of Cracow

Institute of Neophilology

Department of English Linguistics

Karmelicka 41

30-128 Kraków

Poland

lukasz.zarzycki@up.krakow.pl 